\title{
Analysis by RP-HPLC and Purification by RP-SPE of the $C$-Tetra( $p$-hydroxyphenyl)resorcinolarene Crown and Chair Stereoisomers
}

\author{
Alver A. Castillo-Aguirre, Zuly Jenny Rivera Monroy ${ }^{(D)}$, and Mauricio Maldonado \\ Departamento de Química, Facultad de Ciencias, Universidad Nacional de Colombia-Sede Bogotá, Bogota 11001, Colombia \\ Correspondence should be addressed to Mauricio Maldonado; mmaldonadov@unal.edu.co
}

Received 7 December 2018; Revised 10 March 2019; Accepted 27 March 2019; Published 16 April 2019

Academic Editor: Guido Crisponi

Copyright (C) 2019 Alver A. Castillo-Aguirre et al. This is an open access article distributed under the Creative Commons Attribution License, which permits unrestricted use, distribution, and reproduction in any medium, provided the original work is properly cited.

A method for the separation of stereoisomer mixture of the octol $C$-tetra( $p$-hydroxyphenyl)calix[4]resorcinarene that was obtained by an acid cyclocondensation reaction between resorcinol and benzaldehyde is reported in this paper. A crude product from octol formation reaction was analyzed by reverse-phase high-performance liquid chromatography (RP-HPLC), and two well-resolved signals corresponding to the crown and chair isomers were found. A reverse phase in solid-phase extraction (RPSPE) protocol allowed the separation of the two stereoisomers with high purity of each isomer. Finally, the crude and purified stereoisomers were characterized by using FT-IR, ${ }^{1} \mathrm{H}-\mathrm{NMR}$, and ${ }^{13} \mathrm{C}-\mathrm{NMR}$ techniques, confirming the chemical identity of the two isomers and the efficiency in the separation process.

\section{Introduction}

Resorcinarenes are macromolecules with four resorcinol rings linked by methylene bridges $[1,2]$, and they have wide applications in chemical separations [3, 4], in NMR techniques as solvating agents [5], and as chemosensors [6-9], among others. Resorcinolarenes are synthesized by the acidcatalyzed cyclocondensation of resorcinol with aliphatic or aromatic aldehydes [10-12]. Acid-catalyzed condensation reaction by choosing aromatic aldehyde as a starting material usually produces a conformational mixture of two stereoisomers, in different proportions, known as chair and crown (see Figure 1) [13-16]. Of these isomers, the crown stereoisomer is the thermodynamically stable compound; alternatively, the structure of resorcinarenes can be rigidified into a crown by linking the hydroxyl groups of the upper rim, which provides a higher degree of preorganization. Resorcinarenes with substituted methylene bridge are found in crown structure in the crystal state [17-19], and in solution, the isomer may adopt crown and chair structures [20,21]; however, the chair structure can interconvert in the crown structure at high-temperature conditions in the presence of highly polluting metal catalysts $[22,23]$.

The many possible structural variations or resorcinarenes fixed in crown conformation and substituted with aromatic ring in the lower rim lead to potential applications as chemical receptors for molecules and ions [17, 24-27], in absorption of heavy metal ions [28], in lithographic processes [29], and as photoresistant materials for glasses [30] and are used for modification of polymeric surfaces with potential applications as stationary phase in chromatographic methods [31]. Despite the importance of this type of molecules, in terms of their applications, there is only one method reported for their separation, which includes successive crystallizations [32]. Continuing with our studies related to structure and applications of resorcinarenes [33-36], in the present investigation, we show an efficient method for the analysis of this kind of stereoisomers by RPHPLC and it is shown that the mixture can be separated by means of the RP-SPE technique with good yields. 

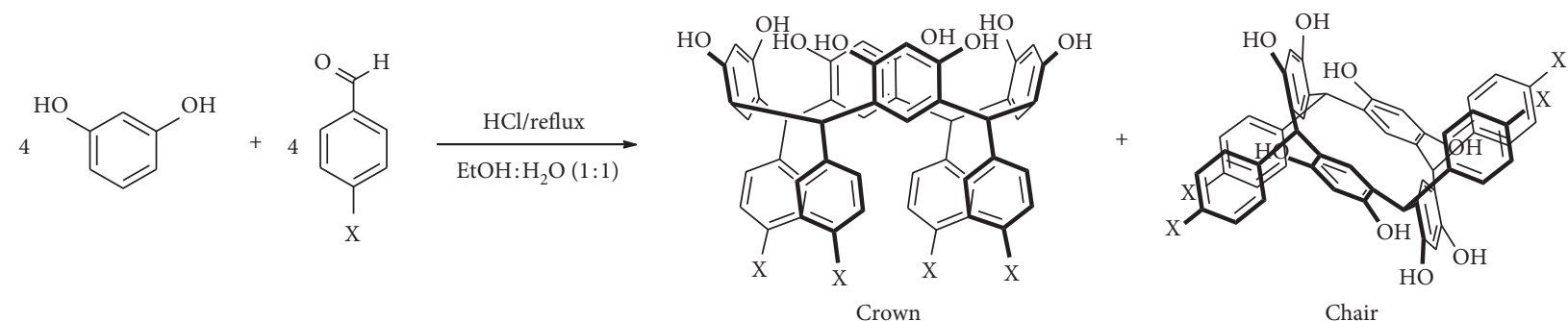

FIgURE 1: Synthesis of aromatic resorcinolarenes.

\section{Materials and Methods}

2.1. General Method. IR spectra were recorded on a Thermo Fisher Scientific Nicolet iS10 FT-IR spectrometer with a Monolithic Diamond ATR accessory and absorption in $\mathrm{cm}^{-1} \cdot{ }^{1} \mathrm{H}$ - and ${ }^{13} \mathrm{C}$-NMR spectra were recorded at $400 \mathrm{MHz}$ on a Bruker Avance 400 instrument. Chemical shifts are reported in ppm, by using the solvent residual signal. The elemental analysis for carbon and hydrogen was carried out using a Thermo Flash 2000 Elemental Analyzer.

\subsection{Synthesis of C-Tetra(p-hydroxyphenyl)resorcinarene} (Stereoisomers Mixture). We followed the method reported by Castillo-Aguirre et al. [36]. A 1,3-dihydroxybenzene solution $(25 \mathrm{mmol})$ and $p$-hydroxybenzaldehyde $(25 \mathrm{mmol})$ in ethyl alcohol: water $(1: 1)(50 \mathrm{~mL})$ was added drop by drop to hydrochloric acid $(5 \mathrm{~mL})$ and was heated at reflux with constant stirring for $4 \mathrm{~h}$. The crude reaction was cooled in ice bath, and the precipitate formed was filtered and washed with mixture ethyl alcohol: water $(1: 1)$ and so with water to remove traces of acid. The filtrate was dried under reduced pressure and was characterized by means of FT-IR, ${ }^{1} \mathrm{H}-\mathrm{NMR}$, and ${ }^{13} \mathrm{C}-\mathrm{NMR}$.

Violet clear solid at a yield of $91 \%$. $\mathrm{Mp}>250^{\circ} \mathrm{C}$ decomposition. FT-IR $\left(\mathrm{KBr} / \mathrm{cm}^{-1}\right)$ : $3384(\mathrm{O}-\mathrm{H}), 1172(\mathrm{C}-\mathrm{O})$; ${ }^{1} \mathrm{H}-\mathrm{NMR}, \mathrm{DMSO}-d_{6}, \delta$ (ppm): 5.43 and 5.52 (s, 4H, ArCH), 5.92-6.10 (s, 4H, ArH, ortho to $\mathrm{OH}), 6.28-6.65(\mathrm{~m}, 20 \mathrm{H}$, $\mathrm{ArH}), 8.37-8.45$ (s, 8OH, ArOH), and 8.68 and 8.85 (s, 4OH, $\mathrm{ArOH})$.

2.3. Separation of the Mixture by RP-HPLC. RP-HPLC analyses were performed over a Kromasil ${ }^{\circledR}$ EternityXT 5-C18 column $(4.6 \times 50 \mathrm{~mm})$ using an Agilent 1200 Liquid Chromatograph (Agilent, Omaha, NE, USA). A gradient ranging from 5 to $50 \%$ of solvent $\mathrm{B}$ (TFA $0.05 \%$ in acetonitrile) in solvent A (TFA $0.05 \%$ in water) was used. The gradient time was 8 minutes, detection was performed at $210 \mathrm{~nm}$, and the flow rate was $2 \mathrm{~mL} / \mathrm{min}$. Sample concentration of $C$-tetra( $p$-hydroxyphenyl)resorcinolarene (conformational mixture) was $1.0 \mathrm{mg} / \mathrm{mL}$, and $10 \mu \mathrm{L}$ was injected.

2.4. Separation of the Mixture by SPE. Supelclean ${ }^{\mathrm{TM}} \mathrm{ENVI}^{\mathrm{TM}}$ 18 SPE cartridges (bed wt. $5 \mathrm{~g}$, volume $20 \mathrm{~mL}$ ) were used. The cartridges were firstly conditioned by $\mathrm{MeOH}$ and $\mathrm{MeCN}$ and then equilibrated with water (containing TFA 0.05\%).
$100 \mathrm{mg}$ of $C$-tetra( $p$-hydroxyphenyl)resorcinolarene (conformational mixture) dissolved in $600 \mu \mathrm{L}$ of DMSO was loaded on the sorbent material. After loading the mixture, the analytes were eluted with different solutions containing solvent $\mathrm{B}$ in solvent $\mathrm{A}$, at different ratios ranging from 0 to $100 \% \mathrm{v} / \mathrm{v}$.

$C$-tetra( $p$-hydroxyphenyl)resorcinarene (crown): violet clear solid in yield $52 \%$. M.p. $>250^{\circ} \mathrm{C}$ decomposition. FT-IR $\left(\mathrm{KBr} / \mathrm{cm}^{-1}\right)$ : $3384(\mathrm{O}-\mathrm{H}), 1076(\mathrm{C}-\mathrm{O}) ;{ }^{1} \mathrm{H}-\mathrm{NMR}, \delta(\mathrm{ppm})$ : 5.52 (s, 4H, ArCH), 6.08 (s, 4H, ArH, ortho to OH), 6.48 (d, $8 \mathrm{H}, \mathrm{ArH}, J=8 \mathrm{~Hz}$ ), 6.50 (s, 4H, ArH, meta to OH), 6.64 (d, $8 \mathrm{H}, \mathrm{ArH}, J=8 \mathrm{~Hz}$ ), 8.45 (s, $8 \mathrm{OH}, \mathrm{ArOH}$ resorcinol), 8.85 (4OH, p-OHAr). ${ }^{13} \mathrm{C}-\mathrm{NMR}, \delta$ (ppm): 40.6 (ArCH), 102.1 (resorcinol C-2), 114.1 (resorcinol C-5), 121.0 (hydroxyphenyl C-3), 129.6 (hydroxyphenyl C-2), 136.0 (hydroxyphenyl C-4), 152.2 (resorcinol C-4), 152.3 (hydroxyphenyl C-1), 154.5 (resorcinol C-1).

$C$-tetra( $p$-hydroxyphenyl)resorcinarene (chair): cream solid in yield $48 \%$. M.p. $>250^{\circ} \mathrm{C}$ decomposition. FT-IR $(\mathrm{KBr} /$ $\left.\mathrm{cm}^{-1}\right): 3401(\mathrm{O}-\mathrm{H}), 1077$ (C-O); ${ }^{1} \mathrm{H}-\mathrm{NMR}, \delta(\mathrm{ppm}): 5.39$ (s, $4 \mathrm{H}, \mathrm{ArCH}), 5.88$ (s, 2H, ArH, ortho to OH), 6.06 (s, 2H, ArH, ortho to $\mathrm{OH}), 6.24(\mathrm{~s}, 2 \mathrm{H}$, ArH, meta to $\mathrm{OH}), 6.27(\mathrm{~s}, 2 \mathrm{H}$, ArH, meta to $\mathrm{OH}), 6.28$ (d, $8 \mathrm{H}, \mathrm{ArH}, J=8 \mathrm{~Hz}), 6.38$ (d, $8 \mathrm{H}$, $\mathrm{ArH}, J=8 \mathrm{~Hz}), 8.31$ (s, 4OH, ArOH resorcinol), 8.35 (s, $4 \mathrm{OH}, \mathrm{ArOH}$ resorcinol), 8.61 (s, $4 \mathrm{OH}, p-\mathrm{OHAr}) .{ }^{13} \mathrm{C}-\mathrm{NMR}$, $\delta$ (ppm): $41.2(\mathrm{ArCH}), 113.9$ (resorcinol C-2), 120.9 (resorcinol C-5), 121.9 (hydroxyphenyl C-3), 129.8 (hydroxyphenyl C-2), 134.5 (hydroxyphenyl C-4), 152.4 (resorcinol C-4), 152.6 (hydroxyphenyl C-1), 154.3 (resorcinol C-1).

\section{Results and Discussion}

As it is shown in Figure 1, the synthesis of resorcinarene was done through the acid-catalyzed cyclocondensation of 1,3dihydrohybenzene with $p$-hydroxybenzaldehyde in a $1: 1$ mixture of ethyl alcohol and water and was heated at reflux by $4 \mathrm{~h}$. The precipitate was characterized using spectral techniques, including FT-IR, ${ }^{1} \mathrm{H}-\mathrm{NMR}$, and ${ }^{13} \mathrm{C}-\mathrm{NMR}$ (see Materials and Methods). C-tetra(p-hydroxyphenyl) resorcinarene had been previously synthesized [36], and the spectroscopic data agreed with those reported in this paper. In this way, the FT-IR spectrum for crude product is in agreement with the organic functionalities present in the structure of the two conformers, as it reveals the hydroxyl group stretches at $3384 \mathrm{~cm}^{-1}(\mathrm{O}-\mathrm{H})$ and $1172 \mathrm{~cm}^{-1}(\mathrm{C}-\mathrm{O})$, whereas the bands of the aryl substituent and the resorcinol ring are also observed. The ${ }^{1} \mathrm{H}-\mathrm{NMR}$ spectrum showed 


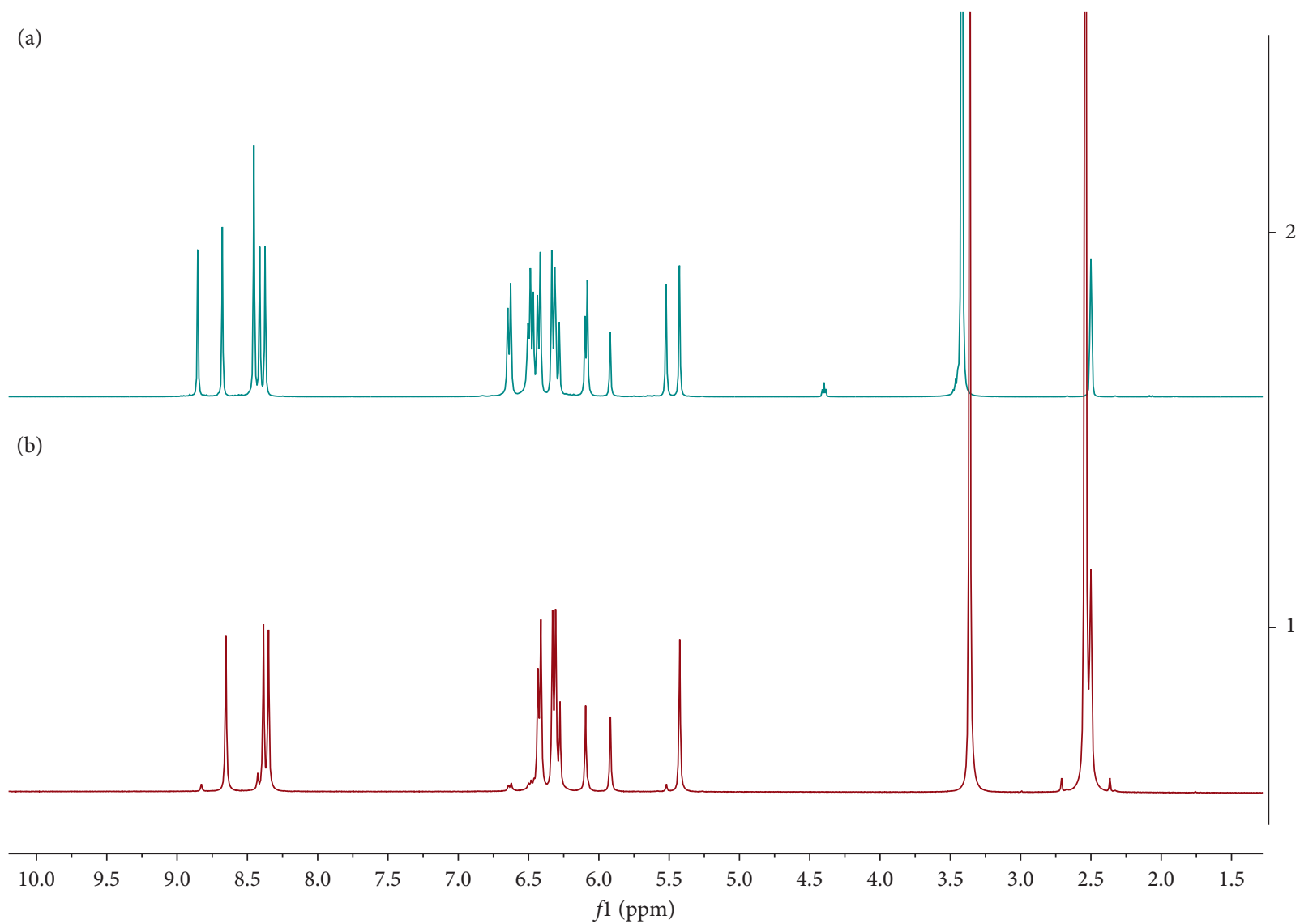

Figure 2: ${ }^{1} \mathrm{H}-\mathrm{NMR}$ spectra to $400 \mathrm{MHz}, \mathrm{DMSO}-d_{6}$, and $293 \mathrm{~K}$. (a) Conformational mixture. (b) Chair isomer.

resonance signals for the aromatic hydrogen atoms for conformer mixture at 5.92 to $6.65 \mathrm{ppm}$, the methylene bridges fragments at 5.43 and 5.52, and the hydroxyl moieties $\left(\delta=8.37\right.$ to $8.85 \mathrm{ppm}$ ) (see Figure $2(\mathrm{a})$ ). In the ${ }^{13} \mathrm{C}$ NMR spectra of the product, there are two signals in the aliphatic region for carbons of the methylene bridge fragment between the aromatic rings. In the aromatic region, the carbon signals for the tetrasubstituted resorcinol unit and aryl chains also showed an increase in the number of signals. The results allow confirming the presence of two stereoisomers for resorcinarene (see Figure 3(a)).

After identifying the presence of the two stereoisomers in the reaction product, it was decided to analyze the mixture by means of RP-HPLC; the crude product was dissolved in DMSO, and it was analyzed using the following gradient program: $5 / 5 / 50 / 100 / 100 / 5 / 5 \% \mathrm{~B}$ at $0 / 1 / 9 / 9.5 / 11 / 11.5 /$ 15 minutes. The chromatographic profile showed the presence of two well-resolved signals $\left(R_{\mathrm{s}}=2.0\right)$ at $t_{\mathrm{R}} 3.42$ and 3.85 minutes (see Figure 4(a)). This result shows us the power of reverse phase for the separation of this kind of stereoisomer mixture.

Then we explore the possibility of scaling the separation up; we had considered RP-SPE as an attractive methodology for the purification of the stereoisomers since the results of Kamysz et al. [37] demonstrated that by means of SPE, it is possible to purify challenging molecules as antimicrobial peptides in a fast and one-step procedure, and this method furnishes products of $>95-97 \%$ purity; moreover, there is no need for sophisticated equipment and consumption of mobile phase is minimal. For the preparative separation, we used commercial cartridges of $5 \mathrm{~g}$ and we loaded them with $100 \mathrm{mg}$ of the mixture dissolved in DMSO; this solvent was removed washing the cartridge with water and then solutions, containing different growing concentrations of solvent $\mathrm{B}$, were passed through. Collected fractions were analyzed by RP-HPLC, and it was found that crown and chair isomers were successfully separated (see Figures $4(\mathrm{~b})$ and $4(\mathrm{c})$ ) in a preparative manner.

To establish the efficiency of the separation of the two stereoisomers, the isolated products by SPE were initially analyzed by ${ }^{1} \mathrm{H}-\mathrm{NMR}$ (Figure 2(b), Table 1). The ${ }^{1} \mathrm{H}-\mathrm{NMR}$ spectra of the first product showed three different hydroxyl moieties at $8.61 \mathrm{ppm}$ assigned to hydroxyl groups in the lower rim and two signals at 8.31 and $8.35 \mathrm{ppm}$ corresponding to hydroxyl groups for two classes of hydroxyl groups attached to resorcinol residues in the macrocyclic system. In the aromatic region, in addition to the signals of the hydroxyphenyl substituent at 6.28 and $6.38 \mathrm{ppm}$, four signals are evidenced in the resorcinol residues, two corresponding to the protons in the ortho position to the hydroxyl group at 5.88 and $6.06 \mathrm{ppm}$ and the other two signals corresponding to the protons in meta position to the hydroxyl groups at 6.24 and $6.27 \mathrm{ppm}$. In this way, these patterns were consistent with the structure of the expected chair stereoisomer. 


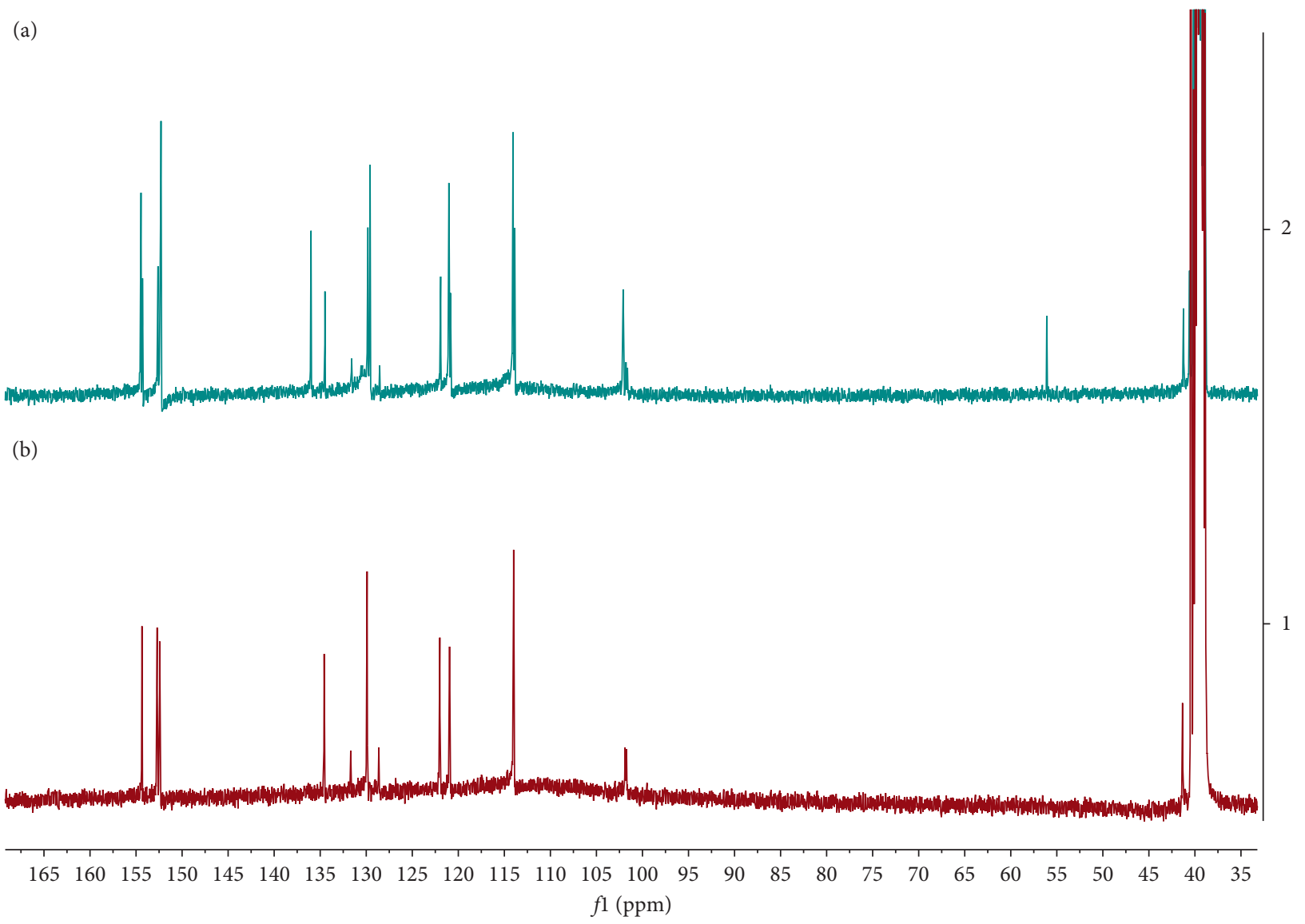

Figure 3: ${ }^{13} \mathrm{C}-\mathrm{NMR}$ spectra to $400 \mathrm{MHz}, \mathrm{DMSO}-d_{6}$, and $293 \mathrm{~K}$. (a) Conformational mixture. (b) Chair conformer.

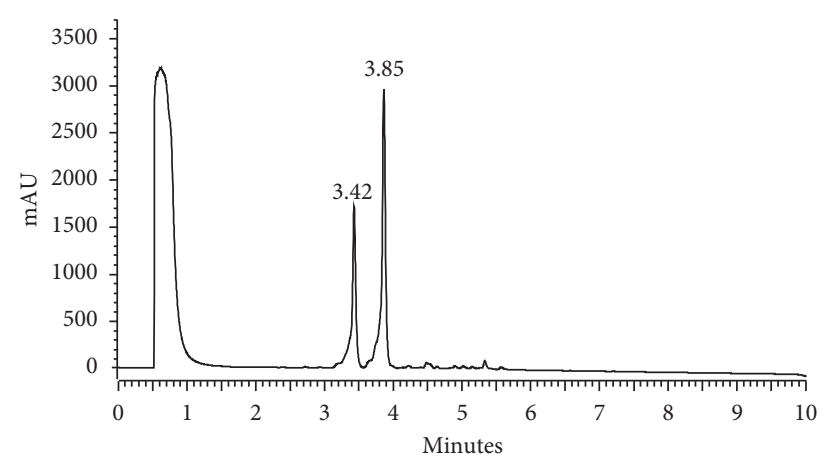

(a)

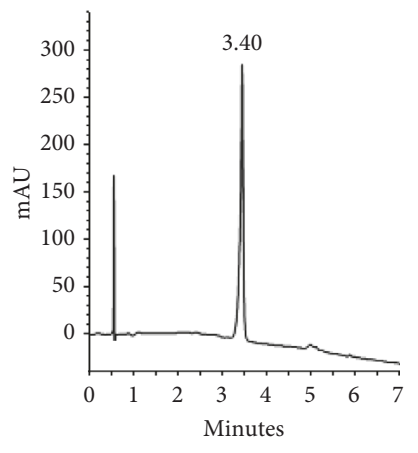

(b)

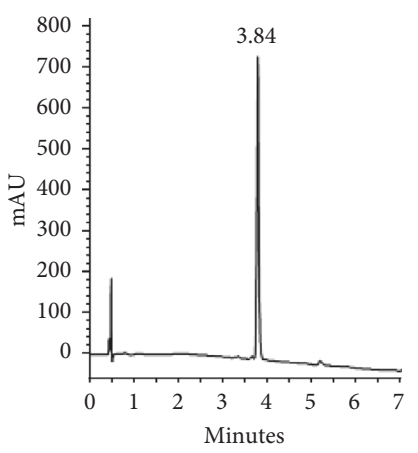

(c)

Figure 4: RP-HPLC profiles. (a) Conformational mixture. (b) Crown conformer. (c) Chair conformer.

On the contrary, the ${ }^{1} \mathrm{H}-\mathrm{NMR}$ spectra of the second product showed two single peaks at 8.85 and $8.45 \mathrm{ppm}$ corresponding to two classes of hydroxyl groups, the first signal corresponding to a hydroxyl group in the lower rim and the second signal for the hydroxyl group in the upper rim. Additionally, all the patterns were consistent with the structure of the expected crown stereoisomer which has few signals in the spectrum.

As shown in Figure 3, in the ${ }^{13} \mathrm{C}$-NMR spectrum, the number of signals for the raw product contrasts with the number of signals of the pure isomer. To confirm that the two products obtained corresponded to the cyclic stereoisomers, the ${ }^{13} \mathrm{C}$-NMR was also obtained. The ${ }^{13} \mathrm{C}-\mathrm{NMR}$ spectra of chair stereoisomer (see Figure 3(b)) displayed characteristic signals of hydroxyphenyl substituent (121.9, $129.8,134.5$, and $152.6 \mathrm{ppm}$ ), and the aromatic carbons of resorcinol appeared at 113.9, 120.9, 152.7, and $154.3 \mathrm{ppm}$. The signal at $41.2 \mathrm{ppm}$ confirmed the presence of a methylene bridge fragment between the aromatic rings. In the same way, the crown stereoisomer showed nine signals, one 
TABLE 1: Chemical shifts for pure stereoisomers crown and chair in ${ }^{1} \mathrm{H}-\mathrm{NMR}$ and ${ }^{13} \mathrm{C}-\mathrm{NMR}$ spectra.

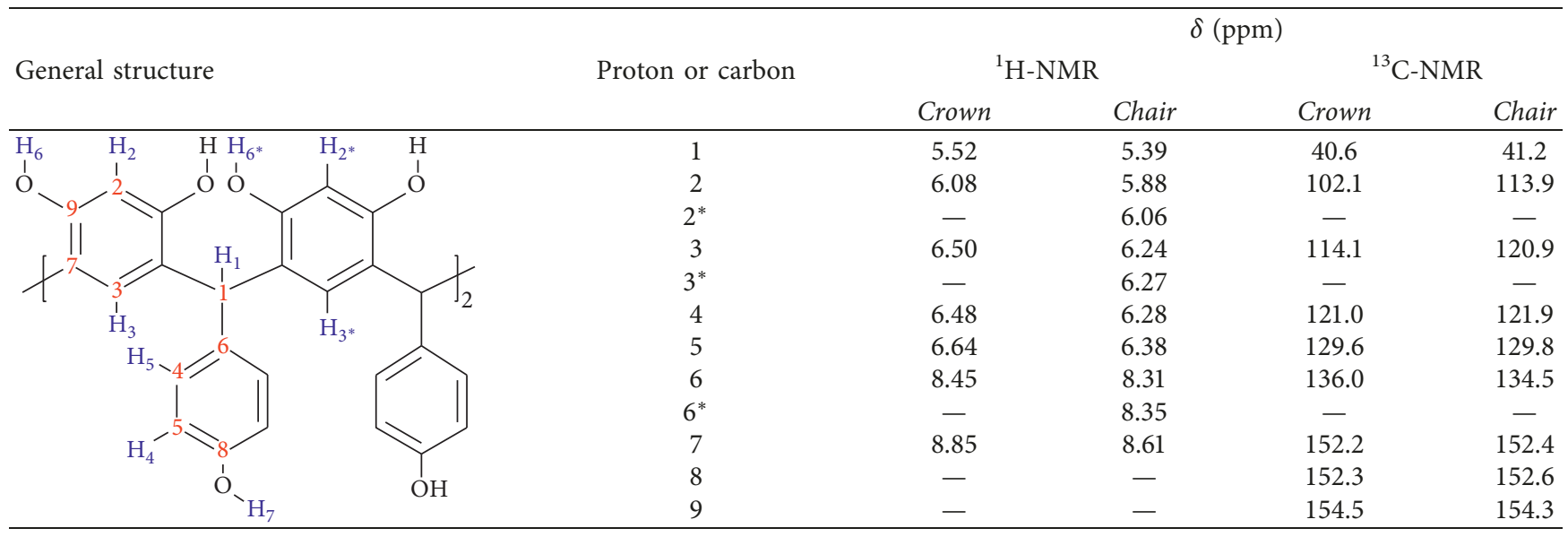

${ }^{*}$ Resolved signal corresponding to the protons of the chair conformer.

at $40.6 \mathrm{ppm}$ confirmed the presence of a methylene bridge fragment between the aromatic rings. The aromatic region showed four signals for hydroxyphenyl substituent at 121.0, $129.6,136.0$, and $152.3 \mathrm{ppm}$ and for the carbons of resorcinol residue appeared at $102.1,114.1,152.2$, and $154.5 \mathrm{ppm}$ (see Table 1).

Finally, comparing conventional crystallization and SPE technique for the separation of stereoisomers of $C$-tetra $(p$ hydroxyphenyl)calix[4]resorcinarene, we found great advantages. Specifically, in a typical crystallization procedure, a small amount of crude product of $C$-tetra( $p$-hydroxyphenyl) calix[4]resorcinarene was dissolved in acetone and stirred for $1 \mathrm{~h}$; after cooling to $0^{\circ} \mathrm{C}$, the remaining residue was filtered and the mother liquor was dried. Acetone extracts most of the chair stereoisomer and the residue left with a mixture of chair and crown stereoisomers, the process must be repeated several times to achieve high purity, and the yield of process is very low for the crown stereoisomer although the stereoisomer chair is obtained with good yield. In contrast with SPE technique, the separation can be carried out with less solvent which reduces purification times and enhances yields in comparison with conventional crystallization. On the contrary, previously we used as separation procedure classic column chromatography and AcOEtbenzene $8: 2$ as eluent solvent [36], and this experimental protocol showed similar results to those obtained by the crystallization technique. The proposed method using SPE has been successfully applied to the separation of the mixture of $C$-tetra( $p$-hydroxyphenyl)calix[4]resorcinarene and it has advantages in terms of selectivity, time of separation, yield, and reproducibility.

\section{Conclusions}

In this study, a mixture of stereoisomers of $C$-tetra $(p$ hydroxyphenyl)calix[4] resorcinarene was obtained from conventional synthesis, and the crude was analyzed by RPHPLC. These stereoisomers were successfully separated by RP-SPE technique. The ${ }^{13} \mathrm{C}$ and ${ }^{1} \mathrm{H}-\mathrm{NMR}$ spectra of each separated conformer confirmed that the separation method was efficient. The developed method was applied and has the advantages of high sensitivity, low running cost, and simple operation and could be applied in the analysis of analogue systems of mixtures of stereoisomers.

\section{Data Availability}

The IR and NMR data used to support the findings of this study are included within the article.

\section{Conflicts of Interest}

The authors declare no conflicts of interest.

\section{Acknowledgments}

The authors gratefully acknowledge the support of Universidad Nacional de Colombia-Sede Bogotá. Alver Castillo thanks the program Colciencias Doctorado Nacional (No. 647) for financing their Ph.D. studies. The authors are grateful to Ana Katherin Gelvez Cortes for the experimental assistance.

\section{References}

[1] A. G. Högberg, "Two stereoisomeric macrocyclic resorcinolacetaldehyde condensation products," Journal of Organic Chemistry, vol. 45, pp. 4498-4500, 1980.

[2] A. G. Högberg, "Stereoselective synthesis and DNMR study of two 1,8,15,22-tetraphenyl[1 4]metacyclophan3,5,10,12,17,19,24,26-octols," Journal of the American Chemical Society, vol. 102, pp. 6046-6050, 1980.

[3] H. Tan, S. Soh, J. Zhao, E. Yong, and Y. Gong, "Preparation and application of methylcalix[4]resorcinarene-bonded silica particles as chiral stationary phase in high-performance Liquid chromatography," Chirality, vol. 23, no. 1E, pp. E91-E97, 2011.

[4] N. Li, R. G. Harrison, and J. D. Lamb, "Application of resorcinarene derivatives in chemical separations," Journal of Inclusion Phenomena and Macrocyclic Chemistry, vol. 78, no. 1-4, pp. 39-60, 2014.

[5] T. J. Wenzel, "Calixarenes and calix[4] resorcinarenes as chiral NMR solvating agents," Journal of Inclusion Phenomena and Macrocyclic Chemistry, vol. 78, no. 1-4, pp. 1-14, 2014. 
[6] Q. Yang, C. Yan, and X. Zhu, "A fluorescent chemosensor for paeonol based on tetramethoxy resorcinarene tetraoxyacetic acid," Sensors Actuators, B Chem.vol. 191, pp. 53-59, 2014.

[7] N. K. Beyeh, D. P. Weimann, L. Kaufmann, C. A. Schalley, and K. Rissanen, "Ion-pair recognition of tetramethylammonium salts by halogenated resorcinarenes," Chemistry-A European Journal, vol. 18, no. 18, pp. 5552-5557, 2012.

[8] K. Salorinne, D. P. Weimann, C. A. Schalley, and M. Nissinen, "Resorcinarene podand with amine-functionalized side armssynthesis, structure, and binding properties of a neutral anion receptor," European Journal of Organic Chemistry, vol. 35, pp. 6151-6159, 2009.

[9] O. Hayashida and M. Uchiyama, "Cyclophane-based tet$\mathrm{ra}($ resorcinarene) as a host for both histone and hydrophobic molecular guests," Tetrahedron Letters, vol. 47, no. 24, pp. 4091-4094, 2006.

[10] L. M. Tunstad, J. A. Tucker, E. Dalcanale et al., "Host-guest complexation. 48. Octol building blocks for cavitands and carcerands," Journal of Organic Chemistry, vol. 54, pp. 1305-1312, 1989.

[11] S. F. Alshahateet, A. G. Jiries, S. A. Al-Trawneh, A. S. Eldouhaibi, and M. M. Al-Mahadeen, "Kinetic, equilibrium and selectivity studies of heavy metal ions ( $\mathrm{Pb}(\mathrm{II}), \mathrm{Co}(\mathrm{II}), \mathrm{Cu}(\mathrm{II}), \mathrm{Mn}(\mathrm{II})$, and $\mathrm{Zn}(\mathrm{II})$ ) removal from water using synthesized C-4methoxyphenylcalix[4]resorcinarene adsorbent," Desalination and Water Treatment, vol. 57, pp. 1-11, 2014.

[12] Y. Yamakawa, M. Ueda, R. Nagahata, K. Takeuchi, and M. Asai, "Rapid synthesis of dendrimers based on calix[4] resorcinarenes," Journal of the Chemical Society, Perkin Transactions, vol. 1, pp. 4135-4139, 1998.

[13] C. R. Pfeiffer, K. A. Feaster, S. J. Dalgarno, and J. L. Atwood, "Syntheses and characterization of aryl-substituted pyrogallol [4]arenes and resorcin[4]arenes," CrystEngComm, vol. 18, no. 2, pp. 222-229, 2016.

[14] T. Tero and M. Nissinen, "A perspective to resorcinarene crowns," Tetrahedron, vol. 70, no. 6, pp. 1111-1123, 2014.

[15] F. Weinelt and H.-J. Schneider, "Mechanisms of macrocycle genesis. The condensation of resorcinol with aldehydes," Journal of Organic Chemistry, vol. 56, no. 19, pp. 5527-5535, 1991.

[16] B. A. Roberts, G. W. V. Cave, C. Raston, and J. L. Scott, "Solvent-free synthesis of calix[4]resorcinarenes," Green Chemistry, vol. 3, no. 6, pp. 280-284, 2001.

[17] S. Senthan and V. Alexander, "Synthesis, luminescence, and electrochemical studies of a new series of octanuclear ruthenium(II) complexes of tolylterpyridine appended calixresorcarenes," Dalton Transactions, vol. 44, no. 33, pp. 14813-14822, 2015.

[18] V. I. Maslennikova, O. S. Serkova, M. Gruner et al., "Synthesis and conformation analysis of new perphosphorylated calix[4] resorcinarenes," European Journal of Organic Chemistry, vol. 2004, no. 23, pp. 4884-4893, 2004.

[19] L. Zhaoa, Y. Wan, S. Huang et al., "Silica sulfuric acidcatalyzed syntheses of calix[4]resorcinarenes," Letters in Organic Chemistry, vol. 10, pp. 298-301, 2013.

[20] K. Deleersnyder, H. Mehdi, I. T. Horváth, K. Binnemans, and T. N. Parac-Vogt, "Lanthanide(III) nitrobenzenesulfonates and p-toluenesulfonate complexes of lanthanide(III), iron(III), and copper(II) as novel catalysts for the formation of calix[4] resorcinarene," Tetrahedron, vol. 63, no. 37, pp. 9063-9070, 2007.

[21] L. Yasmin, T. Coyle, K. Stubbs, and C. L. Raston, "Stereospecific synthesis of resorcin[4] arenes and pyrogallol[4] arenes in dynamic thin films," Chemical Communications, vol. 49, pp. 10932-10934, 2013.

[22] A. G. M. Barrett, D. C. Braddock, J. P. Henschke, and E. R. Walker, "Ytterbium(III) triflate-catalysed preparation of calix[4]resorcinarenes: Lewis assisted Brønsted acidity," Journal of the Chemical Society, Perkin Transactions, vol. 1, no. 8, pp. 873-878, 1999.

[23] K. E. Peterson, R. C. Smith, and R. S. Mohan, "Bismuth compounds in organic synthesis. Synthesis of resorcinarenes using bismuth triflate," Tetrahedron Letters, vol. 44, no. 42, pp. 7723-7725, 2003.

[24] H. Singh and S. Singh, "Synthesis and solvent inclusion complexation studies of benzoyl derivatives of resorcinolaldehyde tetramers by $1 \mathrm{H} \mathrm{NMR}$ and thermogravimetric analysis," Journal of Chemical Research, vol. 2, pp. 72-73, 1997.

[25] L. Sebo, F. Diederich, and V. Gramlich, "Tetrakis(phenylamidinium)-substituted resorcin[4]arene receptors for the complexation of dicarboxylates and phosphates in protic solvents," Helvetica Chimica Acta, vol. 83, no. 1, pp. 93-113, 2000.

[26] J. A. Bryant, M. T. Blanda, M. Vincenti, and D. J. Cram, "Guest capture during shell closure," Journal of the American Chemical Society, vol. 113, pp. 2167-2172, 1991.

[27] F. Tancini, T. Gottschalk, W. Schweizer, F. Diederich, and E. Dalcanale, "Ion-pair complexation with a cavitand receptor," Chemistry-A European Journal, vol. 16, pp. 78137819, 2010.

[28] S. A. Al-trawneh, "Studies on adsorptive removal of some heavy metal ions by calix[4]resorcine," Jordan Journal of Earth and Environmental Sciences, vol. 7, pp. 1-9, 2015.

[29] S. W. Chang, R. Ayothi, D. Bratton et al., "Sub-50 nm feature sizes using positive tone molecular glass resists for EUV lithography," Journal of Materials Chemistry, vol. 16, pp. 1470-1474, 2006.

[30] D. L. VanderHart, V. M. Prabhu, A. De Silva, N. M. Felix, and C. K. Ober, "Solid state NMR investigation of photoresist molecular glasses including blend behavior with a photoacid generator," Journal of the Brazilian Chemical Society, vol. 19, pp. 2683-2694, 2009.

[31] A. A. Castillo-Aguirre, B. A. Velásquez-Silva, C. Palacio, F. Baez, Z. J. Rivera-Monroy, and M. Maldonado, "Surface modification of poly(GMA-co-EDMA-co-MMA) with resorcarenes," Journal of the Brazilian Chemical Society, vol. 29, pp. 1965-1972, 2018.

[32] R. S. Patil, C. Zhang, and J. L. Atwood, "Process development for separation of conformers from derivatives of resorcin[4] arenes and pyrogallol[4]arenes," Chemistry-A European Journal, vol. 22, pp. 15202-15207, 2016.

[33] E. Sanabria, M. A. Esteso, E. Vargas, and M. Maldonado, "Experimental comparative study of solvent effects on the structure of two sulfonated resorcinarenes," Journal of Molecular Liquids, vol. 254, pp. 391-397, 2018.

[34] M. Maldonado, E. Sanabria, B. Batanero, and M. Esteso, “Apparent molal volume and viscosity values for a new synthesized diazoted resorcin[4]arene in DMSO at several temperatures," Journal of Molecular Liquids, vol. 231, pp. 142-148, 2017.

[35] E. Sanabria, M. Esteso, A. Pérez-Redondo, E. Vargas, and M. Maldonado, "Synthesis and characterization of two sulfonated resorcinarenes: a new example of a linear array of sodium centers and macrocycles," Molecules, vol. 20, no. 6, pp. 9915-9928, 2015.

[36] A. Castillo-Aguirre, Z. Rivera-Monroy, and M. Maldonado, "Selective O-alkylation of the crown conformer of tetra(4hydroxyphenyl)calix[4]resorcinarene to the corresponding tetraalkyl ether," Molecules, vol. 22, no. 10, pp. 1-11, 2017.

[37] W. Kamysz, M. Okrój, E. Ł, T. Ossowski, and J. Ł, "Fast and efficient purification of synthetic peptides by solid-phase extraction," Acta Chromatographica, vol. 14, pp. 180-186, 2004. 

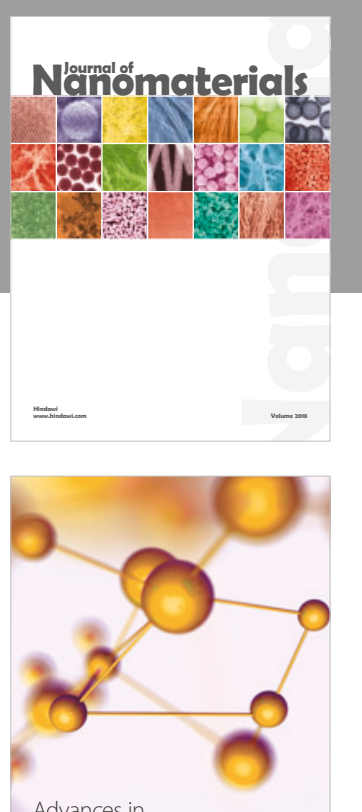

Physical Chemistry
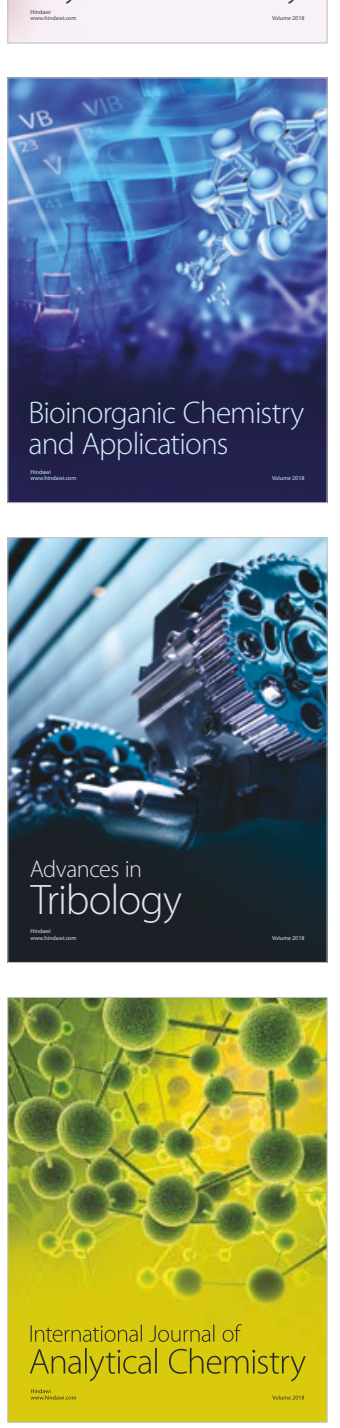

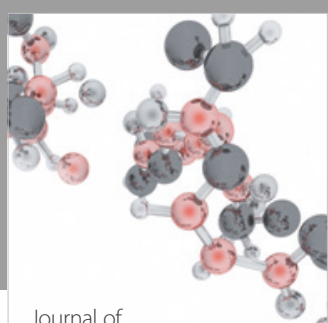

Analytical Methods

in Chemistry

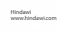

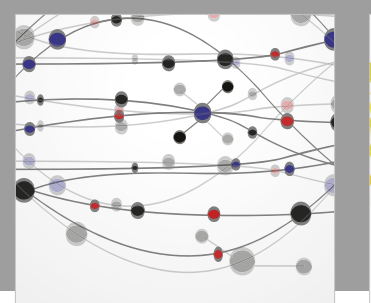

The Scientific World Journal

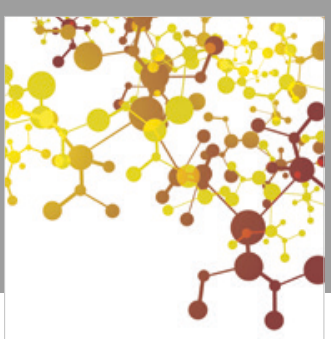

Journal of

Applied Chemistry
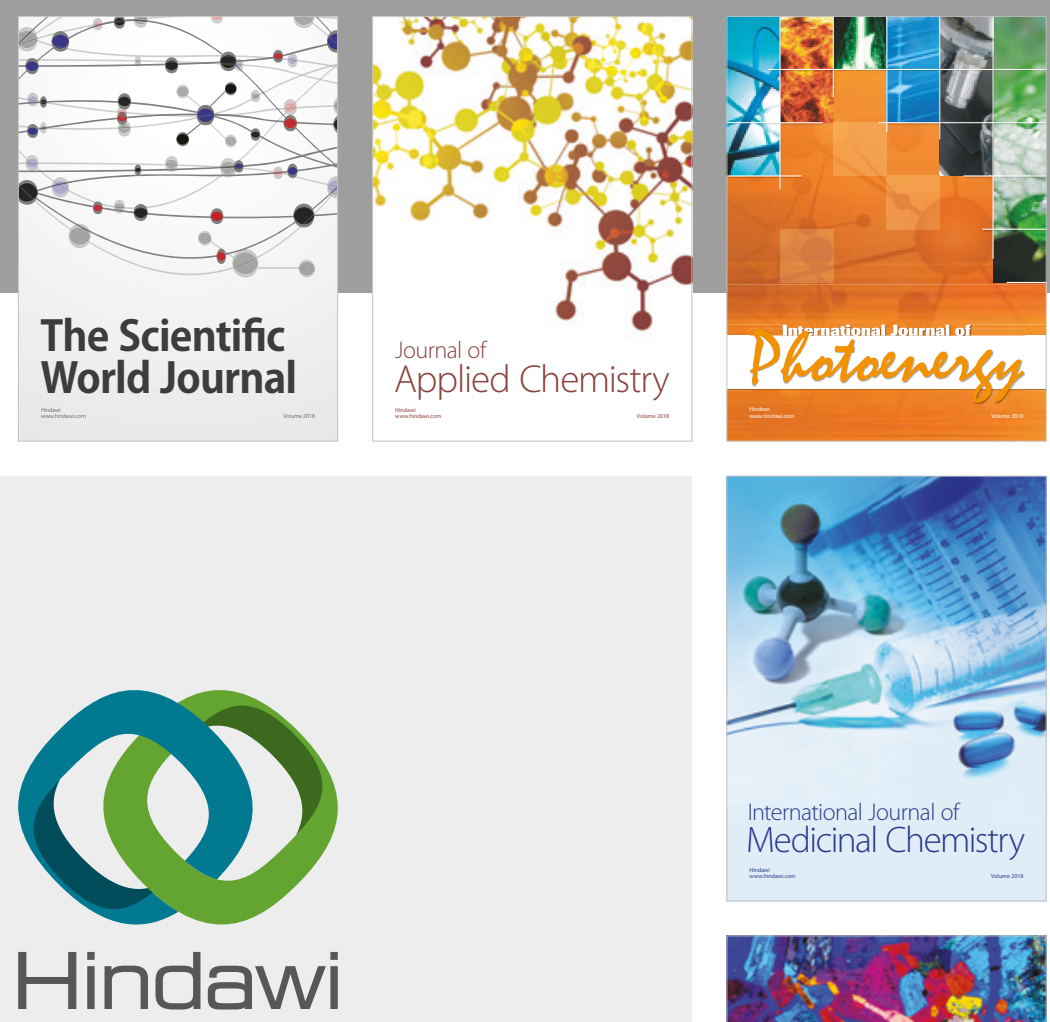

Submit your manuscripts at

www.hindawi.com
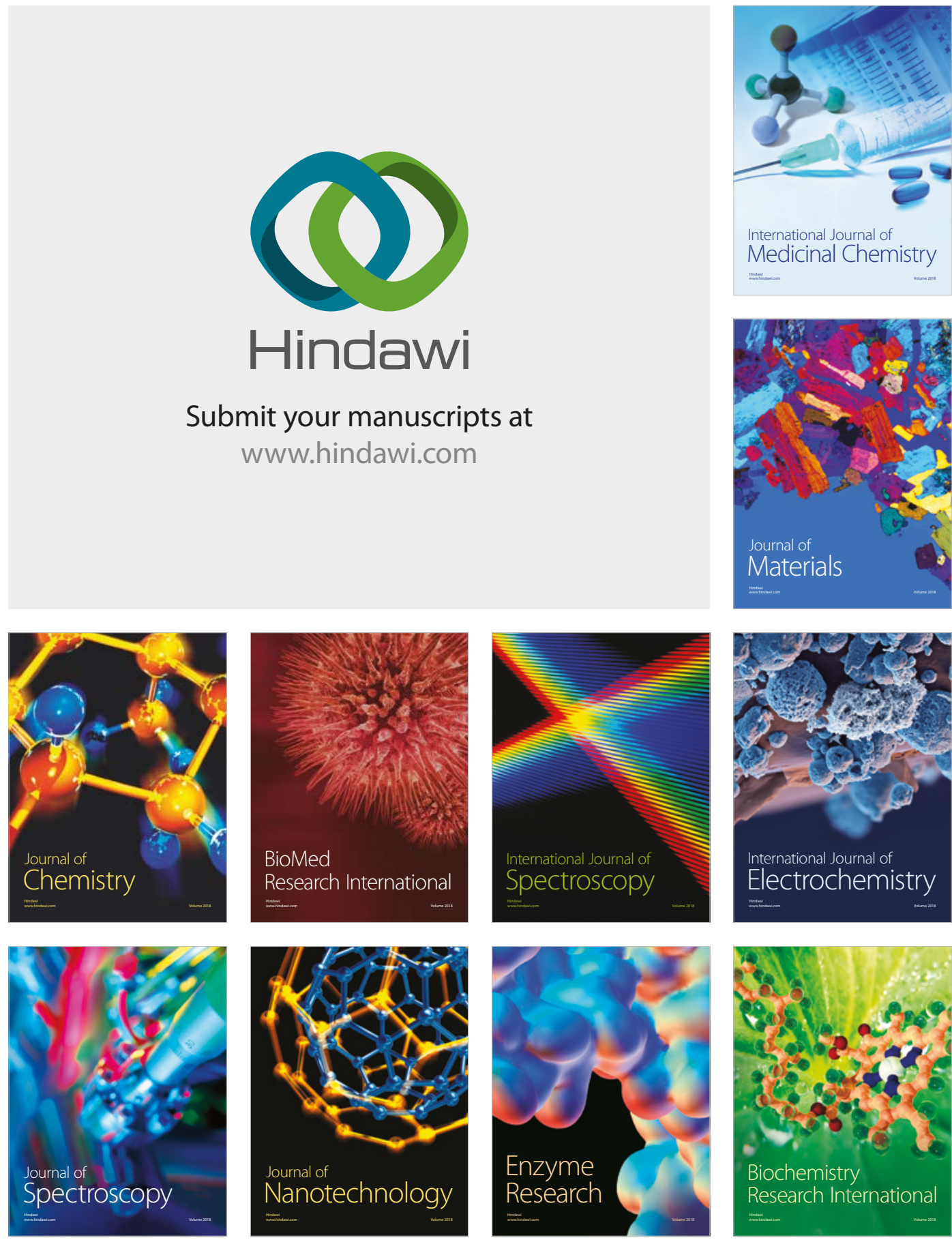
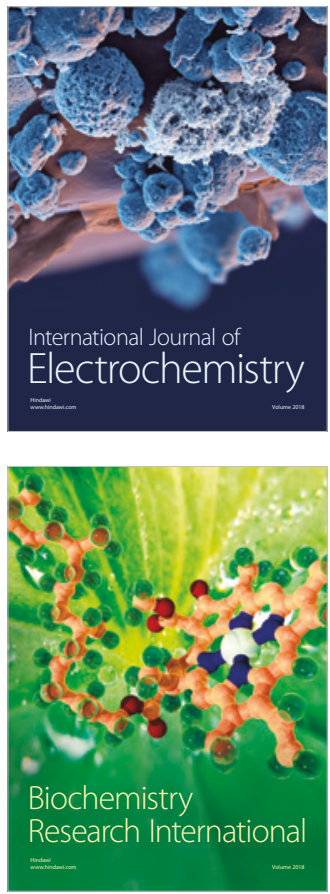